Research Article

\title{
Vitamin D supplementation attenuated carageenan-induced paw edema and formalin-induced nociception in indomethacin-treated rats
}

\author{
Ifeanyi G. Eke*, Chidi Igwe, Aruh O. Anaga
}

Department of Veterinary Physiology and Pharmacology, University of Nigeria Nsukka, Enugu State Nigeria

Received: 9 October 2013 Accepted: 27 October 2013

*Correspondence to:

Dr. Ifeanyi G. Eke, Email: ekeig02@yahoo.com

(C) 2014 Eke IG et al. This is an open-access article distributed under the terms of the Creative Commons Attribution NonCommercial License, which permits unrestricted noncommercial use, distribution, and reproduction in any medium, provided the original work is properly cited.

\begin{abstract}
Background: This work evaluated the effect of vitamin D supplementation on carrageenan-induced paw edema and formalin-induced nociception in indomethacin treated rats.

Methods: Rats were grouped into six $(\mathrm{A}-\mathrm{F})$ of 5 each. Groups $(\mathrm{C}-\mathrm{F})$ were pretreated for 14 days with vitamin D; 250, 500, 1000 and $1000 \mathrm{iu} /$ day respectively. On day 15 , they were treated as follows: group A $(10 \mathrm{ml} / \mathrm{kg}$ distilled water), B; (10 mg/kg indomethacin), C - E; (10 mg/kg indomethacin) F (1000 $\mathrm{iu} /$ day vitamin $\mathrm{D}$ alone). One hour later $50 \mu \mathrm{l} 1 \%$ carrageenan or $25 \mu \mathrm{l} 5 \%$ formalin was injected into the sub-plantal surface of left hind paw. For carageenan-induced paw edema, paw sizes were measured $1 \mathrm{~h}$ later, then every hour for $5 \mathrm{~h}$. For formalin-induced nociception, number of paw licking/lifting was counted for each rat from $0-5$ min (first phase) and $25-30 \mathrm{~min}$ (second phase) post-formalin injection.
\end{abstract}

Results: Paw sizes were significantly $(\mathrm{P}<0.05)$ lower from $2-5 \mathrm{~h}$ postcarageenan injection in the $250 \mathrm{iu} /$ day vitamin $\mathrm{D}+10 \mathrm{mg} / \mathrm{kg}$ indomethacin group when compared with both controls. In the formalin-induced nociception, the 250 $\mathrm{iu} /$ day vitamin $\mathrm{D}+10 \mathrm{mg} / \mathrm{kg}$ indomethacin, $500 \mathrm{iu} /$ day vitamin $\mathrm{D}+10 \mathrm{mg} / \mathrm{kg}$ indomethacin and the $1000 \mathrm{iu}$ /day vitamin D alone groups produced significantly $(\mathrm{p}<0.05)$ lower number of paw lifting when compared with both controls in both phases.

Conclusion: These findings suggest that vitamin D exerts antiinflammatory and antinociceptive responses that could be relevant for clinical application.

Keywords: Vitamin D, antiinflammatory, antinociceptive, indomethacin, supplementation

\section{INTRODUCTION}

Vitamin D is a hormone precursor present in two forms; ergocalciferol or D2 and cholecalciferol or D3. ${ }^{1}$ The major source of vitamin D for humans is sun light. Few food sources naturally contain vitamin D. They include oily fish such as salmon, herring, mackerel and cod liver oil. ${ }^{2}$ Vitamin D is hydroxylated in the liver to 25-hydroxy vitamin $\mathrm{D}(25(\mathrm{OH}) \mathrm{D})$ (vitamin $\mathrm{D} 2)$ and concentrations of Circulating $25(\mathrm{OH}) \mathrm{D}$ are considered an indicator of vitamin D status. ${ }^{3} 25$-hydroxy vitamin $\mathrm{D}(25(\mathrm{OH}) \mathrm{D})$ is converted to 1,25-dihydroxy vitamin D3; 1,25(OH)2D3) (vitaminD3); the biologically active form of vitamin D in the kidney. ${ }^{4}$ Vitamin D is vital for calcium homeostasis therefore important for bone growth and preservation. Antiinflammatory effects of 1,25-Dihydroxyvitamin $\mathrm{D}_{3}$ $\left[1,25(\mathrm{OH})_{2 \mathrm{D} 3}\right]$ has been demonstrated and was shown to inhibit antigen-induced $\mathrm{T}$ cell proliferation and cytokine production. ${ }^{5}{ }^{6}$ Vitamin $\mathrm{D}$ has also been shown to be beneficial in prevention of several autoimmune diseases. ${ }^{7}$ Epidemiologic studies have shown inverse associations between intake of vitamin $\mathrm{D}$ and incidence of multiple sclerosis $^{8}$ and type 1 diabetes. ${ }^{9,10}$ There has been published reports of low vitamin D levels in patients with different pain and inflammatory conditions like constant head ache, migraine, osteoarthritis, cancer, heart diseases, frequent falling, muscle weakness, low pain tolerance etc. ${ }^{11}$ Though not all agreed to the level of vitamin D involvement, high sensitive C-reactive protein; a biomarker of inflammation has been shown to be higher in many inflammatory states in people with hypovitaminosis $\mathrm{D}$ than in people with normovitaminosis $\mathrm{D},{ }^{12}$ therefore suggesting increased inflammatory response in hypovitaminosis D conditions. However, evidence for the antiinflammatory effect of vitamin D from experimental studies using inflammation and pain models are rare. Thus it is not known whether vitamin $D$ exerts antiinflammatory or antinociceptive effects relevant for 
clinical application. Determination of treatment benefits of optimum vitamin D level through supplementation in pain and inflammatory conditions is therefore necessary so as to ascertain if there will be any advantage in increasing vitamin $\mathrm{D}$ intake during painful and inflammatory conditions. This work was designed to study the effect of supplementing vitamin $D$ in rats on pain perception and inflammatory response using experimental pain and inflammation models.

\section{METHODS}

Sixty rats of both sexes (98-150 g) were used for the study. They were provided clean water and fed with pelletized feed (Vital feed® Grand cereal and oil meals ltd plateau state Nigeria). They were acclimatized for 7 days before the experiments. The animal experimental protocol were approved by our institution's experimental animal Ethics Committee of the Faculty of Veterinary medicine, University of Nigeria, Nsukka and in compliance with the Federation of European Laboratory Animal Science Association and the European Community Council Directive of November 24, 1986 (86/609/EEC) (EEC, 1986). Vitamin D (as D3 cholecalciferol) (Puritan's pride INC Oakdale, New York USA). Indomethacin BP (Greenfield pharmaceutical Jiang Su China).

\section{Experimental Design}

Thirty rats were used for each experiment and were grouped into six groups $(\mathrm{A}-\mathrm{F})$ of five each. Groups $\mathrm{C}-$ $\mathrm{F}$ were given vitamin $\mathrm{D}(250,500,1000$ and $1000 \mathrm{iu} / \mathrm{day})$ respectively for 14 day by intragastric gavage. On day 15 , group A received $10 \mathrm{ml} / \mathrm{kg}$ distilled water per os and served as the negative control, while group B - E received $10 \mathrm{mg} / \mathrm{kg}$ indomethacin (reference drug) per os. Group F did not receive indomethacin but was treated previously for 14 days with vitamin D (1000 iu/day).

\section{Antiinflammatory test}

\section{Carrageenan-induced paw edema}

Antiinflammatory effect was tested using carageenaninduced paw edema. ${ }^{13}$ Briefly the baseline left hind paw size of each rat was measured with a veneer caliper. $50 \mu \mathrm{l}$ of $1 \%$ carrageenan was injected into the sub-plantal surface of the left hind paw of each rat $1 \mathrm{~h}$ after treatment and the paw size measured $1 \mathrm{~h}$ later, then every hour up till $5 \mathrm{~h}$. The difference in paw size of each rat over $5 \mathrm{~h}$ was determined and average change in paw size for each group which reflects the degree of inflammation was calculated over $5 \mathrm{~h}$ period. Antiinflammatory response was calculated as follows:

$$
\begin{aligned}
& {\left[\left(\mathrm{AUC}_{\text {control }}-\mathrm{AUC}_{\text {treated }}\right)\right] \times 100} \\
& \mathrm{AUC}_{\text {control }} \\
& \text { (AUC: Area under the Curve) }
\end{aligned}
$$

\section{Formalin-induced paw-licking/lifting}

Antinociceptive effect was tested using formalin-induced paw lifting test. ${ }^{14}$ Briefly $25 \mu l$ of $5 \%$ formalin solution was injected into the sub-plantal surface of the left hind paw of each rat $1 \mathrm{~h}$ post-treatment and the number of paw lifting counted for each rat $0-5$ min (first phase) postformalin injection and at $25-30 \mathrm{~min}$ (second phase). The average paw lifting for each group was calculated for both phases and reflects the degree of nociception. The degree of antinociception was calculated using the formula described by Dambisya and Lee ${ }^{15}$ as follows:

$$
\frac{[(\mathrm{X}-\mathrm{Y})]}{\mathrm{X}} \times 100
$$

Where $\mathrm{X}=$ Mean number of paw lifting by the negative control, $\mathrm{Y}=$ mean number of paw lifting by any of the test groups.

\section{Statistical Analysis}

Data obtained were analyzed using one way analysis of variance. They were separated post hoc using least significant difference (LSD) using Windows SPSS version 15 . Significance was accepted at the probability level $\mathrm{P}<0.05$. Percentages were also calculated where necessary.

\section{RESULTS}

\section{Effect of vitamin D supplementation on carageenan- induced paw edema in indomethacin treated rats}

The effect of vitamin D supplementation on the carrageenan-induced paw edema is presented in fig $1 \mathrm{a}, \mathrm{b}$ $\&$ table 1. Fig 1a shows that the combination of vitamin D $(250 \mathrm{iu} /$ day $)+$ indomethacin $(10 \mathrm{mg} / \mathrm{kg})$ produced significantly $(\mathrm{P}<0.05)$ lower paw edema from $2-5 \mathrm{~h}$ post-carageenan administration compared with both controls. The $500 \mathrm{iu} / \mathrm{day}+10 \mathrm{mg} / \mathrm{kg}$ indomethacin group caused significant $(\mathrm{p}<0.05)$ decrease in foot edema at $4-$ $5 \mathrm{~h}$ post-carageenan administration compared with 10 $\mathrm{ml} / \mathrm{kg}$ distilled water. The groups treated with 1000 $\mathrm{iu} /$ day vitamin $\mathrm{D}+10 \mathrm{mg} / \mathrm{kg}$ indomethacin and 1000 $\mathrm{iu} /$ day vitamin $\mathrm{D}$ alone significantly $(\mathrm{p}<0.05)$ decreased foot edema at $3-5 \mathrm{~h}$ post carageenan injection compared with both controls. There was no significant $(p>0.05)$ difference in the total edema size between the groups, although the combination of $250 \mathrm{iu} /$ day vitamin $\mathrm{D}+10$ $\mathrm{mg} / \mathrm{kg}$ indomethacin produced the lowest edema size (fig 1b). However the combination of $250 \mathrm{iu} /$ day vitamin $\mathrm{D}+$ $10 \mathrm{mg} / \mathrm{kg}$ indomethacin produced the highest (30\%) inhibition of foot edema (table 1).

\section{Effect of vitamin D supplementation on formalin- induced nociception in indomethacin treated rats}

Figures $2 \mathrm{a}, \mathrm{b}, \&$ table 2 present the effect of vitamin D supplementation on the formalin-induced nociception in

\section{Antinociceptive test}




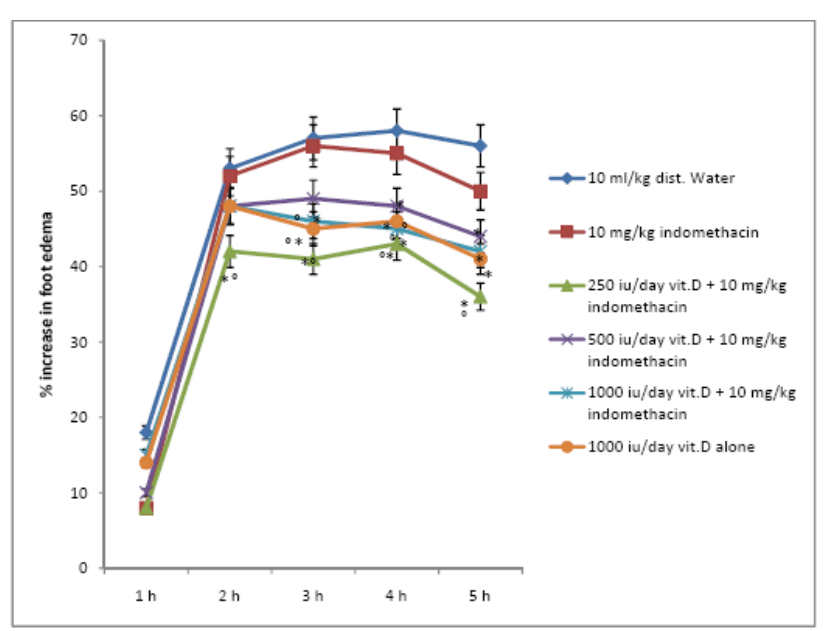

Figure 1a: Percentage increase in foot edema in carageenan-induced foot edema.

* Significant $(\mathrm{P}<0.05)$ compared with $10 \mathrm{ml} / \mathrm{kg}$ distilled water, ${ }^{\circ}$ Significant $(\mathrm{P}<0.05)$ compared with $10 \mathrm{mg} / \mathrm{kg}$ indomethacin

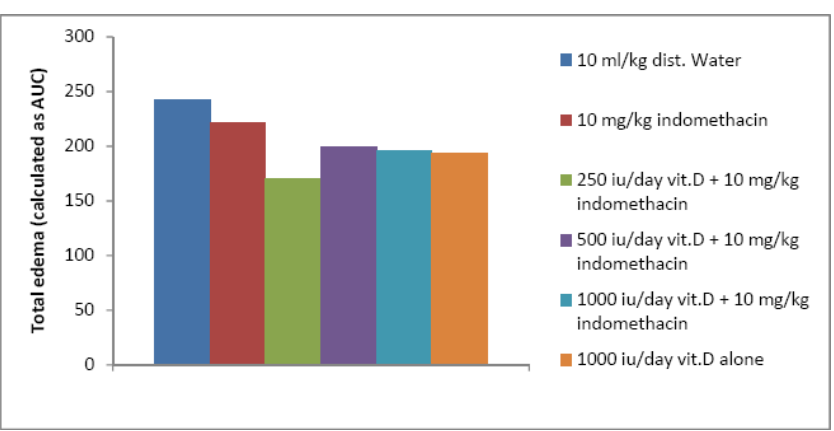

Figure 1b: Total edema calculated as area under the curve (AUC) of increase in foot edema in carageenaninduced foot edema.

Table 1: Percent inhibition of foot edema in carageenan-induced foot edema.

\begin{tabular}{|ll|}
\hline Groups & $\begin{array}{l}\text { \% inhibition of } \\
\text { foot edema }\end{array}$ \\
\hline $10 \mathrm{mg} / \mathrm{kg}$ indomethacin & 9 \\
\hline $\begin{array}{l}250 \mathrm{iu} / \text { day vit.D }+10 \mathrm{mg} / \mathrm{kg} \\
\text { indomethacin }\end{array}$ & 30 \\
\hline $\begin{array}{l}500 \mathrm{iu} / \text { day vit.D }+10 \mathrm{mg} / \mathrm{kg} \\
\text { indomethacin }\end{array}$ & 18 \\
\hline $\begin{array}{l}1000 \mathrm{iu} / \text { day vit.D }+10 \\
\mathrm{mg} / \mathrm{kg} \text { indomethacin }\end{array}$ & 19 \\
\hline $1000 \mathrm{iu} /$ day vit.D alone & 20 \\
\hline
\end{tabular}

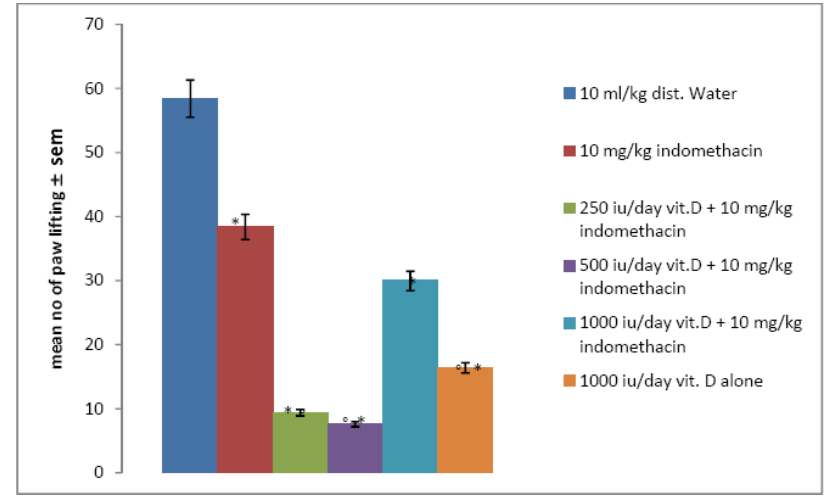

Figure 2a: Mean number of paw lifting/licking in the first phase of formalin-induced nociception.

*Significant $(\mathrm{P}<0.05)$ compared with $10 \mathrm{ml} / \mathrm{kg}$ distilled water, ${ }^{\circ}$ Significant $(\mathrm{P}<0.05)$ compared with $10 \mathrm{mg} / \mathrm{kg}$ indomethacin.

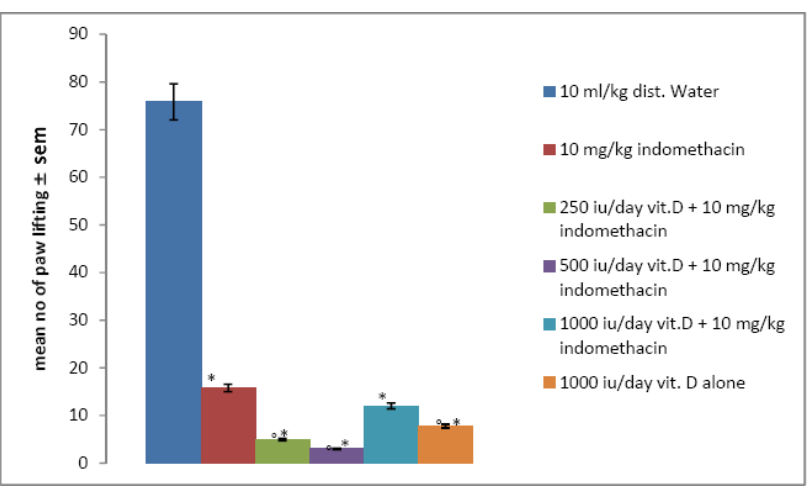

Figure 2b: Mean number of paw lifting/licking in the second phase of formalin-induced nociception.

*Significant $(\mathrm{P}<0.05)$ compared with $10 \mathrm{ml} / \mathrm{kg}$ distilled water, ${ }^{\circ}$ Significant $(\mathrm{P}<0.05)$ compared with $10 \mathrm{mg} / \mathrm{kg}$ indomethacin.

Table 2: Percent inhibition of paw lifting/licking in the first and second phases of formalin-induced nociception.

\begin{tabular}{|lll|}
\hline Groups & $\begin{array}{l}\% \text { inhibition } \\
\text { of paw lifting } \\
\left(1^{\text {st }} \text { phase }\right)\end{array}$ & $\begin{array}{l}\% \text { inhibition } \\
\text { of paw lifting } \\
\left(2^{\text {nd }} \text { phase }\right)\end{array}$ \\
\hline $10 \mathrm{mg} / \mathrm{kg}$ indomethacin & 34 & 79 \\
\hline $\begin{array}{l}250 \mathrm{iu} / \text { day vit.D }+10 \\
\text { mg/kg indomethacin }\end{array}$ & 84 & 93 \\
\hline $\begin{array}{l}500 \mathrm{iu} / \text { day vit.D }+10 \\
\mathrm{mg} / \mathrm{kg} \text { indomethacin }\end{array}$ & 87 & 96 \\
\hline $\begin{array}{l}1000 \mathrm{iu} / \text { day vit.D }+10 \\
\mathrm{mg} / \mathrm{kg} \text { indomethacin }\end{array}$ & 49 & 84 \\
\hline \begin{tabular}{l}
1000 iu/day vit.D alone \\
\hline
\end{tabular} & 72 & 90 \\
\hline
\end{tabular}


rats. Figure $2 \mathrm{a}$ and $\mathrm{b}$ show that all the vitamin $\mathrm{D}$ treated groups except the combination of $1000 \mathrm{IU} /$ day +10 $\mathrm{mg} / \mathrm{kg}$ indomethacin produced significantly $(\mathrm{p}<0.05)$ lower number of paw lifting when compared with both controls. The $1000 \mathrm{IU} / \mathrm{day}+10 \mathrm{mg} / \mathrm{kg}$ indomethacin was only significantly $(\mathrm{p}<0.05)$ lower than $10 \mathrm{ml} / \mathrm{kg}$ distilled water. Table 2 shows that all the vitamin D treated groups have higher pain inhibitory indices (percent inhibition of paw lifting) than $10 \mathrm{mg} / \mathrm{kg}$ indomethacin.

\section{DISCUSSION}

Our findings in this study show that vitamin D attenuated inflammatory and nociceptive responses in rats injected with carageenan and formalin respectively. Carrageenaninduced paw edema is as a result of increase in concentration of prostaglandins and other inflammatory mediators in the inflammatory area which leads to fluid exudation and subsequently edema. ${ }^{16}$ Oxidative stress is thought to play important part in the pathogenesis of inflammation through direct injurious effects and involvement of molecular mechanisms. ${ }^{17}$ Thus reactive oxygen species (ROS) and reactive nitrogen species (RNS) such as $\mathrm{OH}^{-}, \mathrm{H}_{2} \mathrm{O}_{2}$, $\mathrm{NO}$, superoxide radicals play important role in carageenan-induced foot edema in rats. ${ }^{18,19}$ Macrophages also play important role by initiation of a chain of reactions that leads to release of other macrophages and cytokines such as tumor necrosis factor alpha $(\mathrm{TNF} \alpha)$ and interleukin $1 \beta(\operatorname{IL} 1 \beta) .{ }^{19,20}$ These equally have been demonstrated to be involved in carageenan-induced foot edema in rats. ${ }^{20}$ Kinins, histamine and prostaglandins are also released. However vitamin D has been shown to suppress production of IL2, IL6, TNF $\alpha$, interferon $-\gamma .{ }^{21,12}$ There is also report that vitamin $\mathrm{D}$ suppresses the development of an autoimmune disease known as experimental autoimmune encephalomyelitis which is a multiple sclerosis-like condition that are promoted by agents that can stimulate T-helper (Th)-1 cells and that increase interferon- $\gamma$ and TNF- $\alpha$ secretion. ${ }^{22}$ Thus the attenuation of carageenaninduced foot edema in rats by vitamin $\mathrm{D}$ could be related to its ability to inhibit the production of cytokines like IL2, IL6, and TNF $\alpha$. Vitamin D is also known to be a powerful antioxidant and therefore capable of inhibiting the oxidative stress that leads to tissue damage in inflammatory states. Indomethacin is a non-steroidal antiinflammatory agent; an inhibitor of cyclooxygenase 1 (COX1); enzyme required for the synthesis of prostaglandins which play important role in the development of edema during inflammation. ${ }^{23}$ Therefore the stronger antiinflammatory response produced by combination of vitamin $\mathrm{D}$ and indomethacin could be as a result of synergistic effect of both agents in countering different points of the inflammatory cascade. Transient receptor potential ankyrin 1 (TRPA1) is an ion channel involved in thermosensation and nociception and is activated by exogenous irritants and also by oxidants formed in inflammatory reactions. ${ }^{24}$ Formalin-induced nociception has been demonstrated to be mediated by TRPA1. ${ }^{25}$ The first phase of formalin-induced nociception is thought to result from direct activation of primary afferent sensory neurons and are affected only by local anesthetics, whereas the second phase has been proposed to reflect the combined effects of afferent input and central sensitization in the dorsal horn and are affected by many analgesics and intrathecal non-steroidal antiinflammatory agents. ${ }^{25}$ Our results showed decreased response to the effect of intraplantal injection of formalin in vitamin $D$ treated rats in both phases than in both controls, indicating that there is possibility of vitamin D suppressing the activation of TRPA1 by formalin through its antiinflammatory and antioxidant effects. Because there is secretion of inflammatory mediators such as bradykinin, and prostaglandin which are inhibited by indomethacin, it will be logical to assume that there was synergism between both agents and explains the stronger antinociceptive response observed when both agents were combined than when used alone. From this study it seems that the optimum supplementation rate is $250 \mathrm{iu} /$ day since doses above that did not significantly improve antiinflammatory and antinociceptive activity. But the response in rats treated with vitamin $\mathrm{D}$ at the rate of 1000 $\mathrm{iu} /$ day without indomethacin suggests that optimum vitamin D level can improve treatment outcome in inflammatory conditions.

\section{CONCLUSION}

Our findings therefore suggest that there could be a role for vitamin $\mathrm{D}$ in the clinical management of inflammatory and painful conditions. Though more investigations are still needed to determine the extent of vitamin $\mathrm{D}$ requirement and treatment protocol to be adopted in other to exploit the full potential of this vitamin in inflammatory and painful conditions.

Funding: No funding sources

Conflict of interest: None declared

Ethical approval: The study was approved by the Experimental Animal Ethics Committee of the Faculty of Veterinary Medicine, University of Nigeria, Nsukka

\section{REFERENCES}

1. Kulie T, Groff A, Redmer J, Hounshell J, Schrager S. Vitamin D: An Evidence-Based Review. J Am Board Fam Med, 2009; 22( 6): 698-706.

2. Michael FH, Tai CC.Vitamin D deficiency: a worldwide problem with health consequences. Am J Clin Nut, 2008; 87(4): 1080S-1086S.

3. Alvarez JA, Ashraf A. Role of vitamin d in insulin secretion and insulin sensitivity for glucose homeostasis. Int J Endocrinol, 2010; 351-385.

4. Mathieu C, Gysemans C. Vitamin D and diabetes. Diabetol 2006; 22(3): 187-193.

5. Bhalla AK, Amento EP, Serog B, Glimcher LH. 1,25-Dihydroxyvitamin D3 inhibits antigen-induced T cell activation. J Immunol, 1984; 133: 1748-54.

6. Rigby WF, Denome S, Fanger MW. Regulation of lymphokine production and human $\mathrm{T}$ lymphocyte 
activation by 1,25-dihydroxyvitamin D3. Specific inhibition at the level of messenger RNA. J Clin Investigation, 1987; 79:1659-64.

7. Mathieu C, Adorini L. The coming of age of 1,25dihydroxyvitamin $\quad \mathrm{D}(3) \quad$ analogs as immunomodulatory agents. Trends Mol Med, 2002; 8:174-9.

8. Munger KL, Zhang SM, O'Reilly E, et al. Vitamin D intake and incidence of multiple sclerosis. Neurology, 2004; 62: 60-5.

9. Hypponen E, Laara E, Reunanen A, Jarvelin MR, Virtanen SM. Intake of vitamin D and risk of type 1 diabetes: a birth-cohort study. Lancet, 2001;358: 1500-3.

10. Dietrich T, Nunn M, Dawson-Hughes B, Bischoffferrari HA. Association between serum concentrations of 25-hydroxyvitamin $\mathrm{D}$ and gingival inflammation. Am J Clin Nutr 2005; 82(3): 575-580.

11. Krishna GS, Bubblu T, Amarabalan R. Role of vitamin D in diabetes. J Endocrinol Metab, 2011; 1: $47-56$.

12. Sridevi D, Jung-Mi Y, Catherine RD, Ishwarlal J. Low vitamin D correlates with the proinflammatory state in type 1 diabetes subjects with or without microvascular complication. Am J Clin pathol, 2011; 135: 429 - 433.

13. Winter CA, Risley EA, Nuss GW Carrageenaninduced edema in hind paw of the rat as an assay for antiinflammatory drugs. Proc. Soc. Exp. Biol. Med, 1962; 111: 544-547.

14. Dubuisson D, Dennis SG. The formalin test. A qualitative study of the analgesic effects of morphine, meperidine and brain stem stimulation in rats and cats. Pain, 1977; 4: $161-174$.

15. Dambisya YM, Lee TL, (1995). Effect of L-NAME, L-NMMA and L-arginine on the analgesic effect of morphine in mice. Methods Find. Exp Clin Pharmacol, 1995; 17: 577-582.

16. Vinegar R, Truax JF, Selph JL, Johnston PR, Venable AL, McKenzie KK. Pathway to carrageenan-induced inflammation in the hind limb of the rat. Fed Proc, 1987; $46: 118-126$.

17. Cuzzocrea S, Mazzon E, Dugo L, Serraino I, Ciccolo A, Centorrino T, De Sarro A, Achille C. Protective effects of n-acetylcysteine on lung injury and red blood cell modification induced by carrageenan in the rat. The FASEB J, 2001; 15:1187-200.

18. Salvemini D, Wang ZQ, Bourdon DM, Stern MK, Currie MG, Manning PT: Evidence of peroxynitrite involvement in the carrageenan-induced rat paw edema. Eur J Pharmacol, 1996, 303:217-20.

19. Zheng X, Jiangrui Z, Jianmei C, Zhen Z, Xuejun S, Chunlei J. Anti-inflammation effects of hydrogen saline in LPS activated macrophages and carrageenan induced paw oedema. J Inflammation, 2012; 9:2 doi:10.1186/1476-9255-9-2.

20. Banani A, Maleki-Dizaji N, Garjani A, Soraya H, Mostafalou S, Ziaee M. Clavulanic acid exhibits anti-inflammatory effects on carrageenan-induced paw edema model of inflammation in rats. Annals Biol Res, 2012, 3 (7):3312-3320.

21. Lam HY, Schnoes HK, DeLuca HF. 1Hydroxyvitamin $\mathrm{D}_{2}$ : a potent synthetic analog of vitamin $\mathrm{D}_{2}$. Science, 1974; 186:1038-1040.

22. Renno T, Krakowski M, Piccirillo C, Lin J, Owens T. TNF- $\alpha$ expression by resident microglia and infiltrating leukocytes in the central nervous system of mice with experimental allergic encephalomyelitis: regulation by Th1 cytokines. J. Immunol, 1995; 154: 944-953.

23. Rang HP, Dale MM, Rita JM. Pharmacology. $3^{\text {rd }}$ ed. Churchill Livingstone Edinburgh, 1998:251252,645 .

24. Moilanen LJ, Laayola M, Kukkonen M, Korhonen R, Leppanen T, Hogestatt ED, Zygmunt PM, Nieminen RM, Moilanen E. TRPA1 Contributes to the Acute Inflammatory Response and Mediates Carrageenan-Induced Paw Edema in the Mouse. Scientific Reports, 2012:2:380. doi:10.1038/srep00380.

25. Collen RM, Josh MB, Diana MB, Jan S, Kari LD, Michael Z, Neil JH, Jayhong AC David J, Magdalene MM, Christopher MF. TRPA1 mediates formalin-induced pains. Proc Nat Acad Sci U S A. 2007;14(104):13525-30.

doi:10.5455/2319-2003.ijbcp20140227

Cite this article as: Eke IG, Igwe C, Anaga AO. Vitamin D supplementation attenuated carageenaninduced paw edema and formalin-induced nociception in indomethacin-treated rats. Int $\mathrm{J}$ Basic Clin Pharmacol 2014;3:206-10. 